\title{
Heavy rain and strong wind events over Spain during HyMeX SOP1
}

\author{
A. Jansà ${ }^{1}$, J. Campins ${ }^{2}$, M. A. Picornell ${ }^{2}$ and J. A. Guijarro ${ }^{2}$ \\ ${ }^{1}$ Universitat de les Illes Balears, Palma \\ ${ }^{2}$ Spanish Meteorological Agency, Palma
}

Received: 23-X-2013 - Accepted: 6-III-2014 - Translated version

Correspondence to: agusti.jansa@gmail.com

\begin{abstract}
The most significant characteristics of heavy rain cases, plus some strong wind cases, that affected Catalonia, Valencia and the Balearic Islands, as well as some other nearby Spanish regions, during the first experimental campaign (SOP1) of the HyMeX Project are briefly reviewed. Most of these cases correspond to activated intensive observation periods (IOPs) and are documented by an important deployment of extraordinary observation means. The resulting collection of cases can be used for precise verification of high resolution forecast models and their improvement, especially on some specific subjects such as the relation between heavy rain and cyclogenesis.
\end{abstract}

Key words: SOP, HyMeX, Mediterranean, Spain, heavy rain, strong wind, cyclones, flash floods

\section{Introduction}

The international project HyMeX (http://www.hymex. org) has the study of the water balance in the Mediterranean as its overall goal. References to this project and a full description of HyMeX can be found in Quintana et al. (2012). In relation to water balance, HyMeX aims to emphasize extreme aspects of this balance, such as episodes of heavy rain which could lead to flash flooding, or those of strong wind in the sea, capable of generating intense evaporation, with complex marine responses (Quintana et al., 2012; Drobinski et al., 2013). HyMeX is a ten-year project (Ducrocq et al., $2010,2013)$, but it is intended to illustrate extreme phenomena based on field campaigns of several months, aimed at a particular type of feature, and referring to a selected area of the Mediterranean territory. The areas initially selected (target area, TA) are indicated in Figure 1. Field campaigns have the generic name of SOP (Special Observation Period) with an extraordary deployement of observational means. Some of these means are kept constantly active throughout the SOP, but there are others (such as aircraft instrumentation, the constant-level balloons or the supplementary vertical soundings) that are activated on demand, during or in relation to short periods (one or a few days of duration), and which are called IOP (Intense Observation Periods). In addition, each IOP refers to one or more sites on which part of the observational effort is specially focused. Therefore, within each target area (TA) and for each SOP, there are a number of default sites.

The first HyMeX SOP, HyMeX-SOP1, took place between September 5th and November 6th 2012. The phenomena on which SOP1 was focused were heavy rainfall, including related flash floods and orographic rainfall, although some episodes of strong wind were also considered. The geographic area chosen was the north-western Mediterranean (NW Med TA). Within this area, the predetermined land sites that focused part of the observational efforts were Catalonia (CA), Valencia (VA), the Balearic Islands (BA), CévennesVivarais (CV), Corsica (CO), Liguria-Tuscany (LT) and Central Italy (CI). Northeast Italy (NEI) was also included, although it was, in principle, outside the NW Med TA (see Figure 1).

From the climatic point of view, in the north-western Mediterranean, fall, more specifically September and October, is the most likely time for intense rainfall and flash floods (Martínez et al., 2008; Llasat et al., 2010, 2013; Ramis et al., 2013). Hence the congruence between the selected area, type of preferential phenomenon and period for SOP1. 


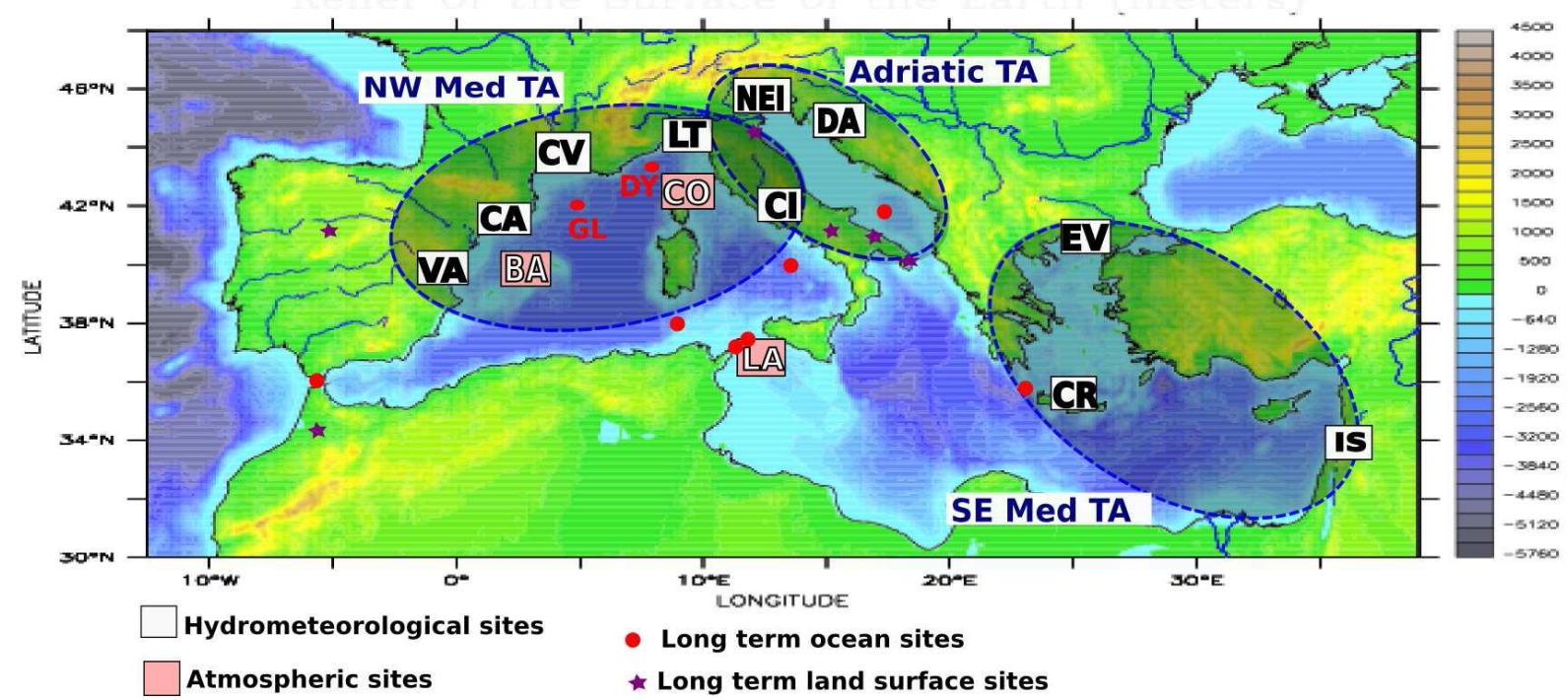

Figure 1. Selected areas (Target Areas, TA) for the HyMeX experimental campaigns (SOP) and sites to be specifically documented. The TA selected for SOP1 was NW Med TA and the land sites in Spain were Catalonia (CA), Valencia (VA) and the Balearic Islands (BA) (Ducrocq et al., 2010).

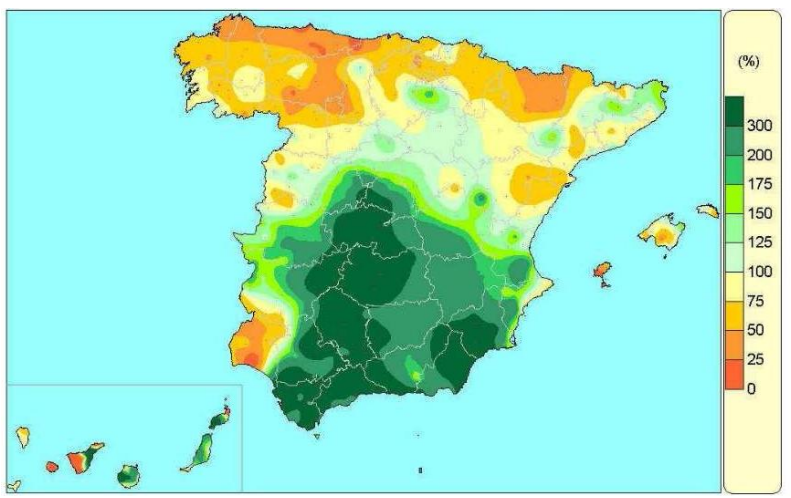

Figure 2. Anomaly of the accumulated rainfall in September 2012, in \% regarding the average for 1971-2000, according to AEMET. A notable surplus, of more than $300 \%$, covers a big part of the south and center of the Iberian Peninsula and spreads through parts of the Valencia region (AEMET, 2012a).

As it has already been said, and as it can be seen in detail in Ducrocq et al. (2013), a series of permanent or semipermanent extraordinary observational means were deployed during the SOP1. These means were focused on the selected sites, especially on CV and also on CO and CI. In the Spanish selected sites no permanent or semi-permanent extraordinary means were deployed, except for a constant-level balloon launching base and a RAMAN LIDAR station (to obtain profiles of water vapor and aerosol), both located at facilities on the island of Menorca. But it must be said that some operating observation means (such as radars or surface weather stations, both those of the Spanish Meteorological Agency
AEMET- and those of the Meteorological Service of Catalonia-SMC-) were given a dissemination that they normally do not have, even being used in real time and for their assimilation in numerical models.

There were also means, especially instrumented aircraft, balloons and constant-level balloons, which were only activated on demand for certain IOPs. It should be mentioned that there were two French instrumented aircraft (from SAFIRE), based in Montpellier, and a German one, based in Corsica. The base for the constant-level balloons release was Menorca, as mentioned above. These balloons obtained measurements of temperature, pressure, humidity and wind along the path, almost horizontal and free. As for the French aircraft, which flew over the territory of Catalonia, Valencia, the Balearic Islands and its vicinity, they were the ATR 42 and the Falcon F20. The low-level ATR42 was equipped with a series of instruments, which, in addition to the basic parameters (temperature, pressure, humidity and wind), allowed turbulence and flow to be measured, as well as distribution of solid and liquid particles of various size ranges, including those related to cloud microphysics. The aircraft was also equipped with a LIDAR LEANDRE to get down profiles of water vapor and particles. Regarding the high-level F20, besides basic instrumentation, it carried a RASTA radar, to obtain vertical profiles, from top to bottom, of reflectivity and Doppler wind, and instrumentation for cloud microphysics. It also had equipment for descending surveys (dropsondes).

Finally, extraordinary radiosoundings were done on demand from a number of operative stations in accordance with the data targeting (DT) philosophy, as used in projects such as MEDEX. Like MEDEX, this DT sounding cam- 


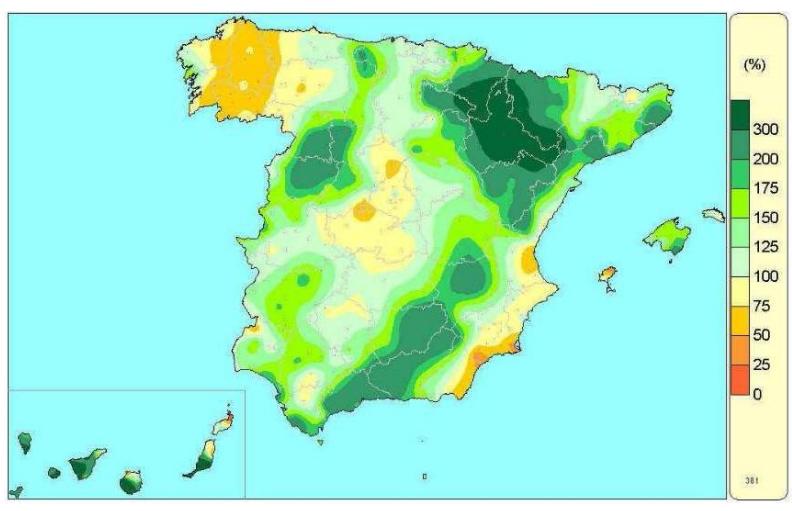

Figure 3. Anomaly of the accumulated rainfall in October 2012, in $\%$ regarding the average for 1971-2000, according to AEMET. The maximum for that month, above $300 \%$, corresponds to the Ebro Valley. Also in Catalonia and Mallorca there is clearly more abundant rainfall than for the climatic average (AEMET, 2012b).

paign was supported by EUMETNET-EUCOS and used the DTS system of the European Centre-Met Office (Jansà et al., 2011). Radiosounding stations participating in this campaign had been previously selected. In total (Europe and Atlantic islands), 29 stations were chosen. Among those located in Spanish territory, five AEMET ones (A Coruña, Madrid, Murcia, Palma and Tenerife) and that of the SMC (Barcelona) were selected. Section 4 specifies what extraordinary surveys were done from these stations on the days of most interest for the area and on the previous day(s).

It should be understood that the fact that this paper only details the extraordinary observation means deployed in Spain or from Spain does not mean that other means were not important for the investigation of the episodes considered here, which are those that affected Catalonia, Valencia, the Balearic Islands and some other Spanish regions.

To analyze meteorological events of interest, to control the operation of the systems, to enable on-demand systems and to announce, declare and close IOPs, a SOP Operations Center was needed (Quintana et al., 2012; Ducrocq et al., 2013). In fact, a Main Operations Center, based in La Grande-Motte, near Montpellier, where the chief scientist and head of operations of the SOP, assigned for partial periods, and two secondary centers, based in the AEMET headquarters in the Balearic Islands, in Palma, and the Italian city of L'Aquila, were constantly operating. In addition, there were complementary centers in San Giuliano (Corsica), Toulouse and Menorca. All these centers were linked by videoconference (with at least a daily briefing). During part of the SOP, there was also a daily link with AEMET headquarters in Madrid, to maintain contact and collaboration between HyMeX and the AEMET experiment on nowcasting severe weather events. The secondary center of Palma held a special watch on the selected sites nearby (Catalonia, Valencia and the Balearic Islands), with occasional extension to the rest of Spain, including suggestions and guidelines for exploration by aircraft or balloon. It also played a role in the activation of the radiosoundings of the DTS (data targeting system). Therefore, for the SOP1 debriefing session, summaries on cases that had affected Spain were ordered (Jansà, 2013) and also on radiosoundings (Campins, 2013).

To facilitate the daily briefing and monitoring the situations in real time, a website containing information about data, discussions and decisions, as well as results for a wide range of numerical weather prediction models ( 35 models), hydrological (3 models) and oceanic (3 models), provided by participating institutions, was constructed and made available. Regarding meteorological models, the SMC contributed with the WRF-ARW M-CAT of $12 \mathrm{~km}$ horizontal resolution and the WRF-ARW MCAT of $4 \mathrm{~km}$. AEMET made available the $5 \mathrm{~km}$ HIRLAM and the AEMET-SREPS ensemble forecasting. The AROME WMED model, $2.5 \mathrm{~km}$, of Météo-France, must also be mentioned, as it is the adaptation for the western Mediterranean of the regular AROMEFrance, with experimental assimilation of complementary surface and radar data.

The aim of this paper is to describe the main episodes of heavy rain (and strong wind) that affected the Spanish territory (particularly in selected sites) during HyMeX-SOP1, indicating some of their features, the extraordinary observations done and some issues that these cases may have raised. The aim is to appeal to the scientific community to study and use these cases, to benefit from the availability of data and the synergies that the HyMeX framework undoubtedly provides. Section 2 provides a brief assessment of what September and October 2012 were like from a climate point of view. Section 3 presents a list of cases. Section 4 is devoted to briefly reviewing some of these cases, and Section 5 makes a final valuation and leaves some questions open.

\section{Climatological balance of September and Octo- ber 2012}

In relation to the objectives of the HyMeX SOP1, the climatic behavior of September and October 2012 was considered, on the whole, quite favorable, although September was less active than October and early November (Ducrocq et al., 2013).

As for Spanish areas, the climatological summaries published by AEMET (AEMET, 2012a, 2012b) can be used to specify the general balance of the campaign.

Figures 2 and 3 show, in particular, the monthly anomalies of rainfall in September and October. There were no significant episodes during the first days of November in our areas of interest.

Throughout Spain there had been significant rainfall in these two months, clearly above average, although it must be highlighted that the largest positive anomalies (Andalusia, Murcia and the center of the peninsula in September, and middle valley of the Ebro, to the Aragonese Pyrenees in October) do not fall within the area of greatest interest to SOP1 of HyMeX. As mentioned in the AEMET 
Table 1. List of cases of interest (with rainfall of over $60 \mathrm{~mm} \mathrm{day}^{-1}$ ). From 07 UTC of the indicated day (yyyymmdd) to $07 \mathrm{UTC}$ of the following day (maximum rainfall, third column, refers in general to this period). If an IOP is established at CA, VA or BA, the affected zone or zones are indicated. In brackets, the IOPs defined only for French or Italian regions. SW means strong wind. Data archived at the AEMET climatic databank. Bnn indicates the constant-level balloon numbered nn. ATR42 is the SAFIRE ATR42 aircraft, at low or medium level. F20 is the SAFIRE Falcon-20, at high level. The episodes with an asterisk are commented on in section 4.

\begin{tabular}{|c|c|c|c|}
\hline Pluviometric day & IOP-areas & Maximum rainfall - area & Notes and operations area (area) \\
\hline $20120912^{*}$ & (IOP2) & $65,2-\mathrm{CA}$ & $\begin{array}{c}\text { Active cold front at CA-BA, } \\
\text { local floods, } \\
\text { tornado at BA }\end{array}$ \\
\hline 20120923 & (IOP5) & (72,5-Pyrenees) & \\
\hline $20120927^{*}$ & (IOP7b) & (245,0-Andalusia) & Floods \\
\hline $20120928^{*}$ & IOP8-VA-CA-BA & 188,9-VA, (241,6-Andalusia, 204,2-Murcia) & $\begin{array}{c}\text { Floods (Murcia), } \\
\text { Tornado at VA, } \\
\text { ATR42 (BA), F20 (VA), } \\
\text { B20 (BA, very short) }\end{array}$ \\
\hline $20120929 *$ & IOP8-VA-CA-BA & 114,2-CA, (143,0-Andalusia) & \\
\hline $20121012^{*}$ & IOP12b-BA & $132,0-\mathrm{BA}, 120,5-\mathrm{VA}$ & $\begin{array}{c}\text { Strong gusts and } \\
\text { floods at BA, F20 (BA) }\end{array}$ \\
\hline 20121014 & (IOP13) & $82,6-\mathrm{BA}$ & \\
\hline 20121018 & (IOP14) & (130,0-Aragon, 113,4-Peninsular center) & \\
\hline $20121019^{*}$ & (IOP14) & (234,0-Pyrenees-Aragon) & Floods (Pyrenees-Aragon) \\
\hline $20121020^{*}$ & IOP15a-VA-CA-BA & 140,0-VA, 121,2-CA, (141,0-Pyrenees-Aragon) & ATR42 (BA), F20 (CA), B23 (CA) \\
\hline 20121024 & & $(84,0$-Andalusia $)$ & \\
\hline $20121025^{*}$ & IOP16a-CA & 145,0-CA, (181,5-Andalusia) & $\begin{array}{c}\text { Local floods CA, } \\
\text { later SCM near CA, } \\
\text { B26 (CA, night } 25 \text { to } 26), \\
\text { ATR42 (CA-BA, night } 25 \text { to } 26)\end{array}$ \\
\hline $20121027^{*}$ & (IOP16bSW), (IOP16c) & 88,5-BA. (95,0-Andalusia) & $\begin{array}{c}\text { Active cold front, } \\
\text { seguit de vent fort CA-BA }\end{array}$ \\
\hline $20121028^{*}$ & (IOP16bSW), (IOP16c) & (107,0-Andalusia) & $\begin{array}{l}\text { Front fred actiu, } \\
\text { followed by strong wind CA-BA }\end{array}$ \\
\hline $20121030^{*}$ & IOP18-CA-BA + SW-BA & $96,8-\mathrm{CA}$ & B13 (CA), B31 (CA) \\
\hline $20121031^{*}$ & IOP18-CA-BA + SW-BA & $88,0-\mathrm{CA}$ & Cyclone with strong wind at BA \\
\hline
\end{tabular}

summaries, these important highs are, largely, the result of two unique events: on 27th-29th September, particularly affecting Malaga and Murcia, and on 19th-20th October, affecting the Ebro valley. The rest of each month was not very productive in terms of heavy rain, especially September.

It is of interest that the region that traditionally accumulates stronger rainfall, which is south of Valencia and north of Alicante (Safor and Marina Alta) (Font, 1983; Ramis et al., 2013) showed a deficit this year, particularly in October. Therefore, the most iconic episodes of heavy rainfall were missing, but there was enough variety and abundance of episodes. We can talk, in that case, about quite favorable conditions.

\section{List of cases of interest}

Table 1 specifies the most interesting cases that affected Catalonia (CA), Valencia (VA) and the Balearic Islands (BA) and some other close areas in the Spanish territory (in parentheses in Table 1).

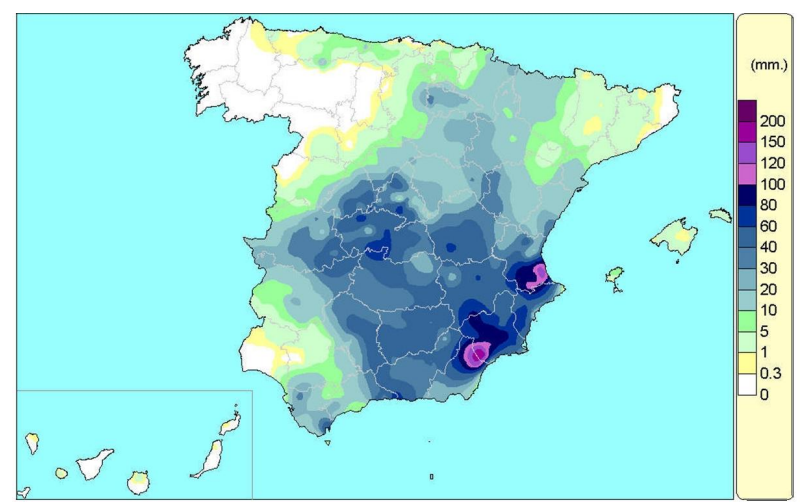

Figure 4. AEMET analysis of rainfall from 06 UTC on 28th September 2012 to 06 UTC on the 29th (provisional data from the automatic stations).

In relation to this table, it should be mentioned that the maximum amounts of rainfall listed are those that were recorded in the AEMET weather database. 

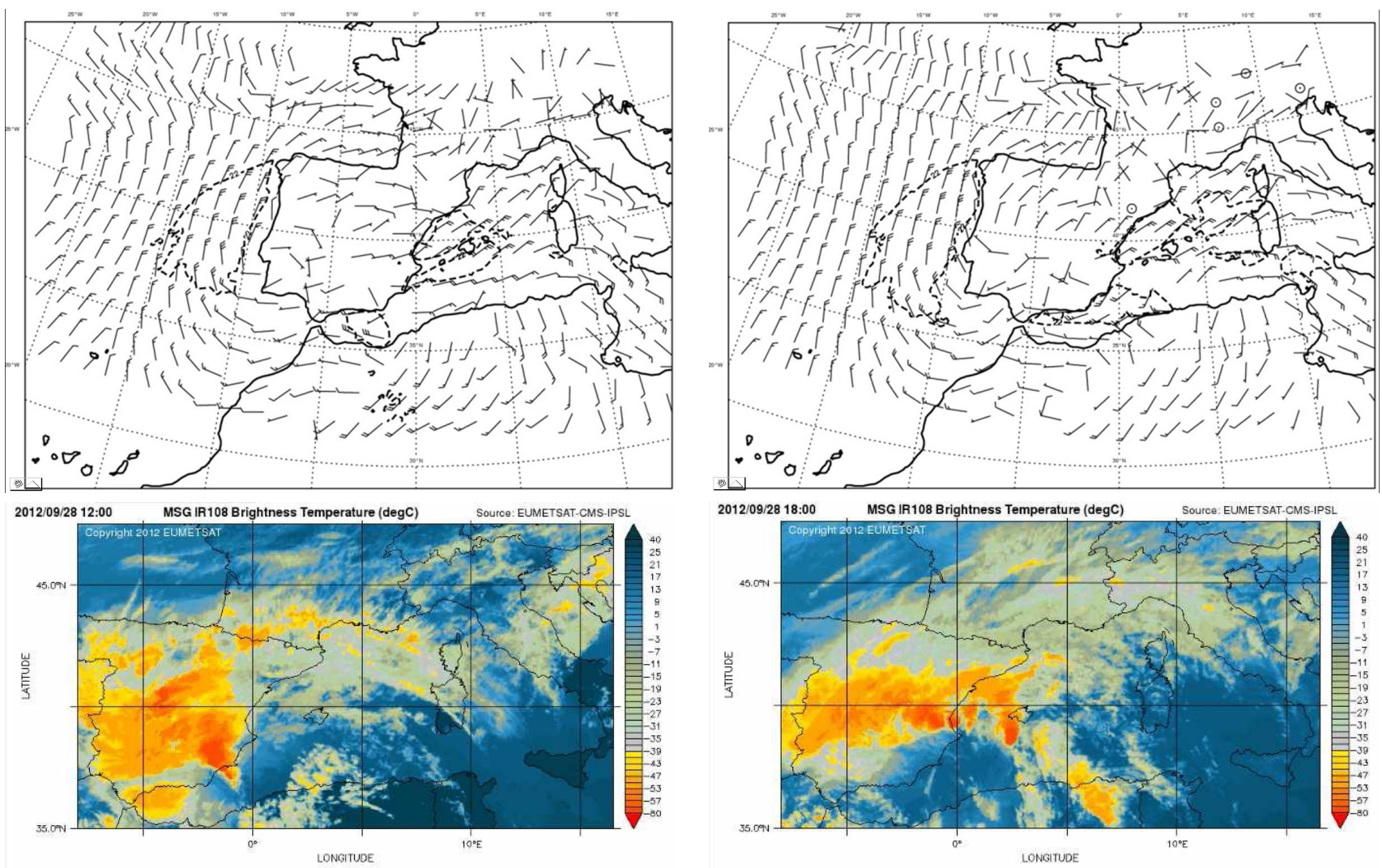

Figure 5. Wind analysis at $10 \mathrm{~m}$ (above), according to HIRLAM-0.05 of AEMET, on 28th September 2012 at 12 UTC (left) and at 18 UTC (right), showing a convergence zone, first over Murcia and later over the south of Valencia and the Balearic Islands, associated to a more or less organized convection (below), according to MSG-IR-10.8 (Eumetsat). The dash line in the wind analysis closes the areas where the wind (sustained) was over $25 \mathrm{kts}$.

Regarding the highlighted operations, the only constantlevel balloons or SAFIRE aircraft flights related are those that happened near one of our selected areas (CA, VA, BA). In the case of balloons, this criterion refers only to the end of the flight, as the initial part is always within the BA area, because the releasing base was in Menorca. Regarding extraordinary DTS-type radiosoundings, they were done each day listed in the table, at 06 or $18 \mathrm{UTC}$, according to the specifications indicated in the corresponding sections of section 4.

The majority of situations listed in Table 1 will be briefly discussed below.

\section{Comments on the situations of interest}

\subsection{Situation on 12th September 2012}

There was relatively significant rainfall in Catalonia and the Balearic Islands (up to $65 \mathrm{~mm}$ in Catalonia, particularly in LEstartit, and up to $42 \mathrm{~mm}$ in the Balearic Islands, in Lluc), with local floods in Catalonia. They were convective type rainfall associated with an active cold front, which was quite severe. A tornado is noteworthy in this regard, possibly
F1 or even F2, in Lluc, coinciding with the maximum rainfall. There was significant damage and evacuation of people. By chance, the tornado passed near the AEMET weather station in Lluc, so there was a partial recording, with a maximum wind gust of $148 \mathrm{~km} \mathrm{~h}^{-1}$.

There was no declared IOP for the region, although there was for NEI (Northeast Italy). On the 12th, extraordinary surveys (DTS) were done at 06 UTC, in A Coruña and Madrid. Another one was done on the 11th at 18 UTC in Madrid.

\subsection{Situation from 27th to 29th September 2012 (IOP8)}

This is the most significant situation which affected areas of Spain during SOP1. This situation included IOP8, which is one of three IOPs selected for an initial analysis in the article that summarizes SOP1 from an international perspective (Ducrocq et al., 2013). The event began on the pluviometric day of September 27th, in the region of Andalusia, in the south of the Iberian Peninsula. The maximum recorded was $245 \mathrm{~mm}$ (specifically in Alpandeire, located inland of the province of Malaga, in central/southern Andalusia). For the 28th and 29th, however, an IOP was declared in the re- 

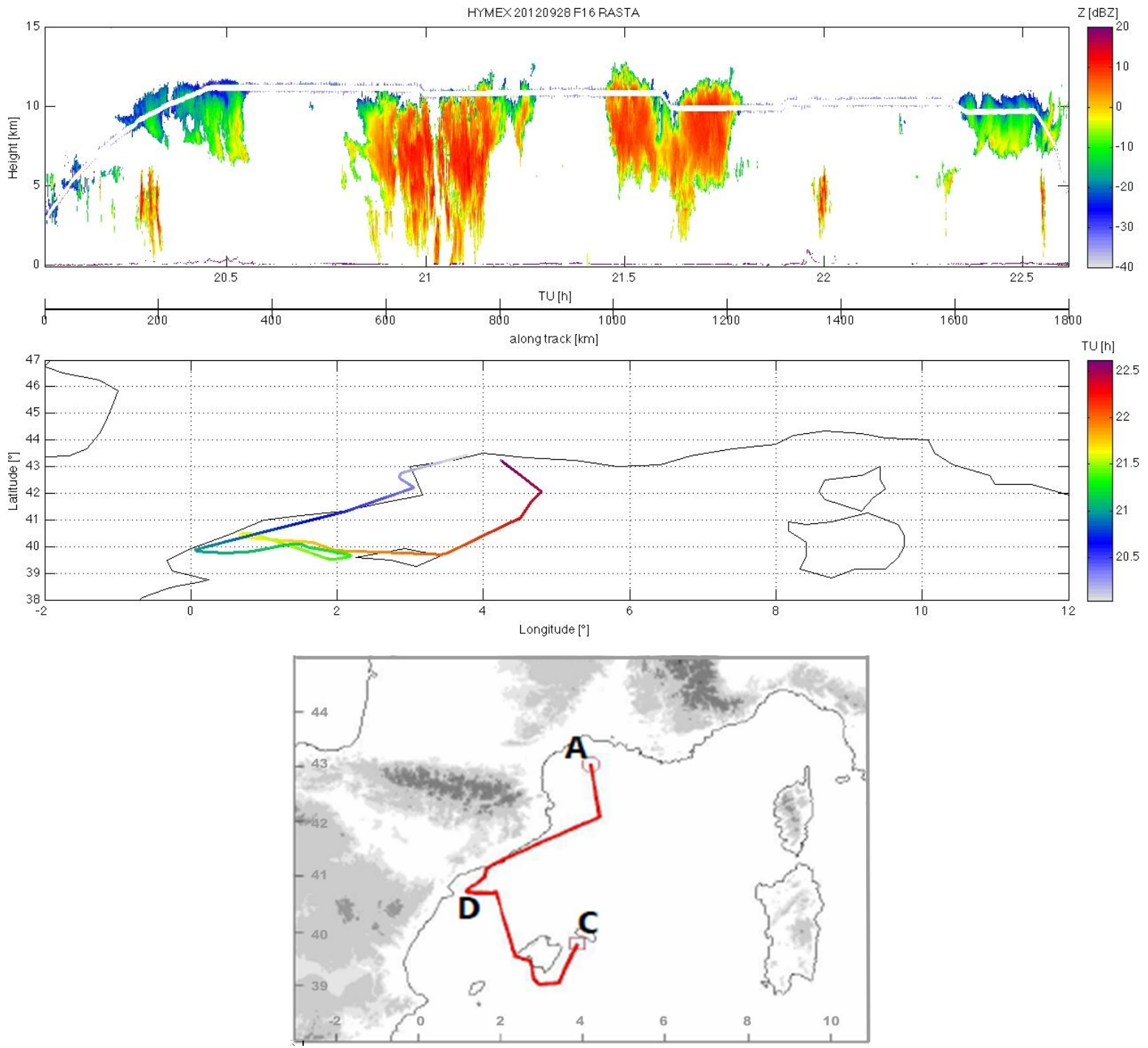

Figure 6. Trajectory of ATR42 between 17:52 and 20:16 UTC on 28th September 2012, leaving from Menorca (third), and reflectivity of the aero transported RASTA radar (first) and trajectory (second) of the F20, between 19:58 and 22:44 UTC on the 28th (data provided by SAFIRE and LATMOS, from the specific website open for the HyMeX SOP1).

gion (IOP8), specifically for VA, CA and BA. In fact, there was significant rainfall, above $100 \mathrm{~mm}$, in Valencia on the 28th and in Catalonia on the 29th, although the most important rainfall was in Andalusia (242 mm in Huércal, province of Almeria, just south-east of Andalusia) and Murcia (a region between Andalusia and Valencia). Specifically, $204 \mathrm{~mm}$ were recorded in Puerto Lumbreras, with its maximum intensity around noon on the 28th (up to $27 \mathrm{~mm}$ in 10 minutes). There was no intense rainfall in the Balearic Islands. Figure 4 shows the pluviometric analysis of AEMET for the 28th (pluviometric day). The maximum in Valencia for the 28th was in the airport: $189 \mathrm{~mm}$.

The event, including the 27 th, was defined by a high level cut-off low, which followed the general circulation to the south of the Iberian Peninsula, on the 27th, and then moved to the north-east to the Gulf of Lion (on the 29th).
In association with this high level perturbation, a depression and convergence zone was formed at low levels, also mobile, where convection is continuously being regenerated. On the 28th, around noon, the convection was very organized and there was a mesoscale convective system, with a typical V-shape, over the region of Murcia. Later, when the perturbed area reached Valencia and the Balearic Islands, in an appropriate location to be explored by research aircraft, the convection, although presenting linear organization, was not as compact as hours earlier, although there was still heavy rain in Valencia and the sea (see Figure 5). On the last day, the 29th, there was significant rainfall in Catalonia, up to $114 \mathrm{~mm}$ (Vilanova de Sau, in the province of Barcelona), but with no extreme intensities.

On September 28th 2012, significant observational efforts were made during the late evening in the IOP activated 


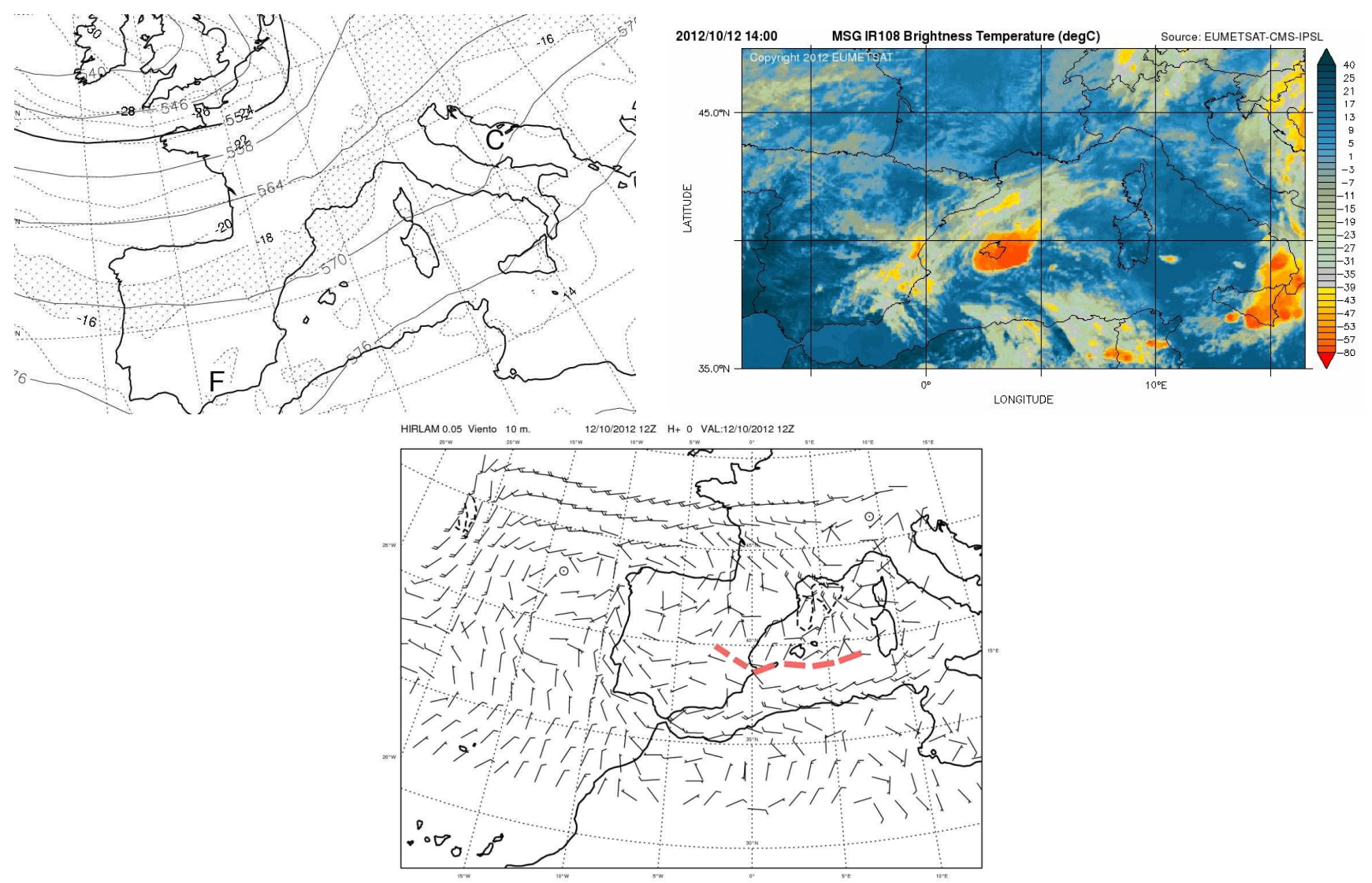

Figure 7. HIRLAM-AEMET analysis, October 12th at 12 UTC (left), of geopotential and temperature at $500 \mathrm{hPa}$ (above) and of wind at $10 \mathrm{~m}$ (down), showing a convergence zone (colored line). The situation of the convective system at 14 UTC, MSG-IR-10.8 (Eumetsat) can be seen up to the right.

area (VA, CA, BA). Figure 6 shows the trajectories of the SAFIRE, the ATR42 (between 17:52 UTC and 20:16 UTC, leaving from Menorca) and the F20 (between 19:58 UTC and 22:44 UTC) aircraft, with the perturbation located in Valencia and the Balearic Islands. The ATR42 explored the feeding current of the convection and made a first journey between Montpellier (south of France) and Menorca. The F20 Falcon did seven dropsondes in the convective zone and nearby and explored this area in situ, with the instrumentation mentioned in the Introduction.

A constant-level balloon, B20, was released from Menorca, heading to Valencia, but it had to stop before entering Mallorca, since flybys over an inhabited area were not authorized except for releasing the balloons.

On the 29th, there were no observations with constantlevel balloons or airplanes of CA-VA-BA.

Regarding extraordinary radiosounding (DTS), there were some from the 25th at 18 UTC until the 29th at 18 UTC, at 06 UTC and at 18 UTC. Barcelona and Murcia did all the releases mentioned, while A Coruña did not do them on the 29th, Madrid did not do those of the 26th at 18 UTC or the 27th at 06 UTC, and Palma did not do the first two (25th at 18 UTC and 26th at 06 UTC). Tenerife did all extraor- dinary soundings from the 26th at 18 UTC to the 28th at 18 UTC. A total of 44 extraordinary soundings were done for this episode.

Regarding social impact, the full episode was quite shocking. According to press reports, in Andalusia and Murcia there were 13 deaths and hundreds of displaced people. The damage exceeded 120 millions of euros, because of floods that affected bridges, roads, etc. The flow of the local river grew in Puerto Lumbreras, Murcia, from almost zero to more than $2000 \mathrm{~m}^{3} \mathrm{~s}^{-1}$. When the perturbation approached the area of Valencia, winds were significant enough to cause maritime problems, such as some beached boats. There was also a tornado that affected recreational facilities in Gandia (Valencia).

\subsection{Situation on 12th October 2012 (IOP 12b)}

This situation, which had a short duration, resulted in the activation of an IOP for the Balearic Islands, IOP12b with special observations. Although a weak trough at high levels and a line of convergence, which was not very marked, at low levels (see Figure 7) was recognized, forcings were not very significant, but they should have been quite well matched for 

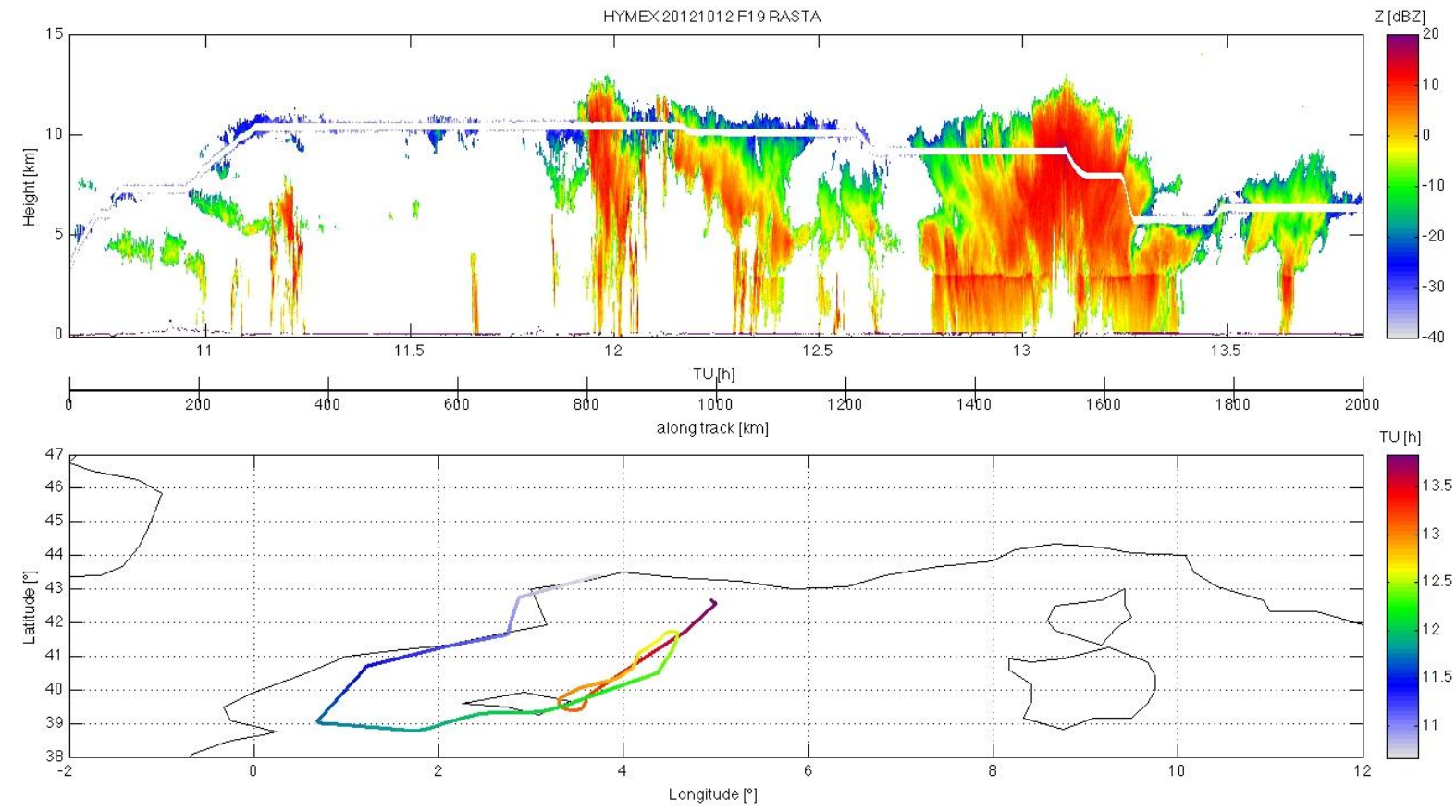

Figure 8. Flight of the Falcon F20, between 10:30 and 14:00 UTC on 12th October 2012. Trajectory (below) and RASTA reflectivity (above) (data provided by SAFIRE and LATMOS, from the specific website open for the HyMeX SOP1).

high resolution models (not shown) to indicate the formation of a convective system, with heavy rain, in the Balearic Islands. In fact this system was formed (Figure 7) and led to severe convection over Mallorca and its vicinity, with hailstones, strong wind and heavy rain. AEMETs Sineu station, located in the geographic center of the island, recorded sudden wind gusts of $107 \mathrm{~km} \mathrm{~h}^{-1}$ and rainfall of $132 \mathrm{~mm}, 36$ of which fell in just ten minutes.

Subsequently, other important convective centres were formed, one of which hit Valencia with a maximum precipitation of $121 \mathrm{~mm}$ at Tavernes de Valldigna (near the coast, $40 \mathrm{~km}$ south of the city of Valencia).

The convective system on the Balearic Islands was explored in detail by the F20 Falcon of SAFIRE between 12 UTC and 14 UTC, while still on the islands (see Figure 7 and Figure 8). Apart from the in situ and radar (RASTA) measurements taken, different dropsondes were released.

Regarding DTS extraordinary soundings, they were not done on the 12th at 06 (from Spain) and on the 12th at 18 UTC they were done from Barcelona, Palma and Murcia. On the previous days (the 10th at 18 UTC and the 11th at 06 UTC and 18 UTC), there were a total of 13 extraordinary soundings from A Coruña, Barcelona, Madrid, Palma or Murcia. Naturally, this information prior to the episode is also useful to study it.

There were significant impacts, such as local flooding and wind effects, as well as alteration of land and air transit; twelve aircraft were diverted from Mallorca to Menorca.

\subsection{Situation on 19th and 20th October 2012 (IOP15a)}

This situation began to affect an outer region that was under the surveillance of HyMeX SOP1. In fact, on 19th October intense rainfall occurred in the Aragonese and Navarra sides of the Ebro basin, corresponding to the most important precipitation over the Aragonese Pyrenees region (Figure 9), where up to $234 \mathrm{~mm}$ were recorded (Canfranc, in the province of Huesca), resulting in rivers bursting their banks and damage of considerable magnitude, including the displacement of people.

As shown in Figure 9, the weather conditions between the 19th and the 20th (within the pluviometric day of October 19th) tended to heavy rain in the Pyrenees, with a very strong trough over the west of the Iberian Peninsula and a vigorous southern flow, fully crossed over the mountain. This situation later evolved into another more favorable one of heavy rain in Catalonia and also in Valencia and the Balearic Islands, tending to close a cold low, isolated in height, centered over the south-east of the Iberian Peninsula, and forming a depression at low levels in the Balearic Sea area (Jansà et al., 2001; Campins et al., 2006; Campins et al., 2007; Martínez et al., 2008).

Because of this, IOP15a was triggered on October 20th in Catalonia, Valencia and the Balearic Islands. Apart from the fact that abundant rain continued in parts of the Aragonese Pyrenees (Barbastro, $141 \mathrm{~mm}$ ), in the Mediterranean, there were heavy rain centres -of more than $100 \mathrm{~mm}$ in the north of Valencia and south of Catalonia, as per Fig- 

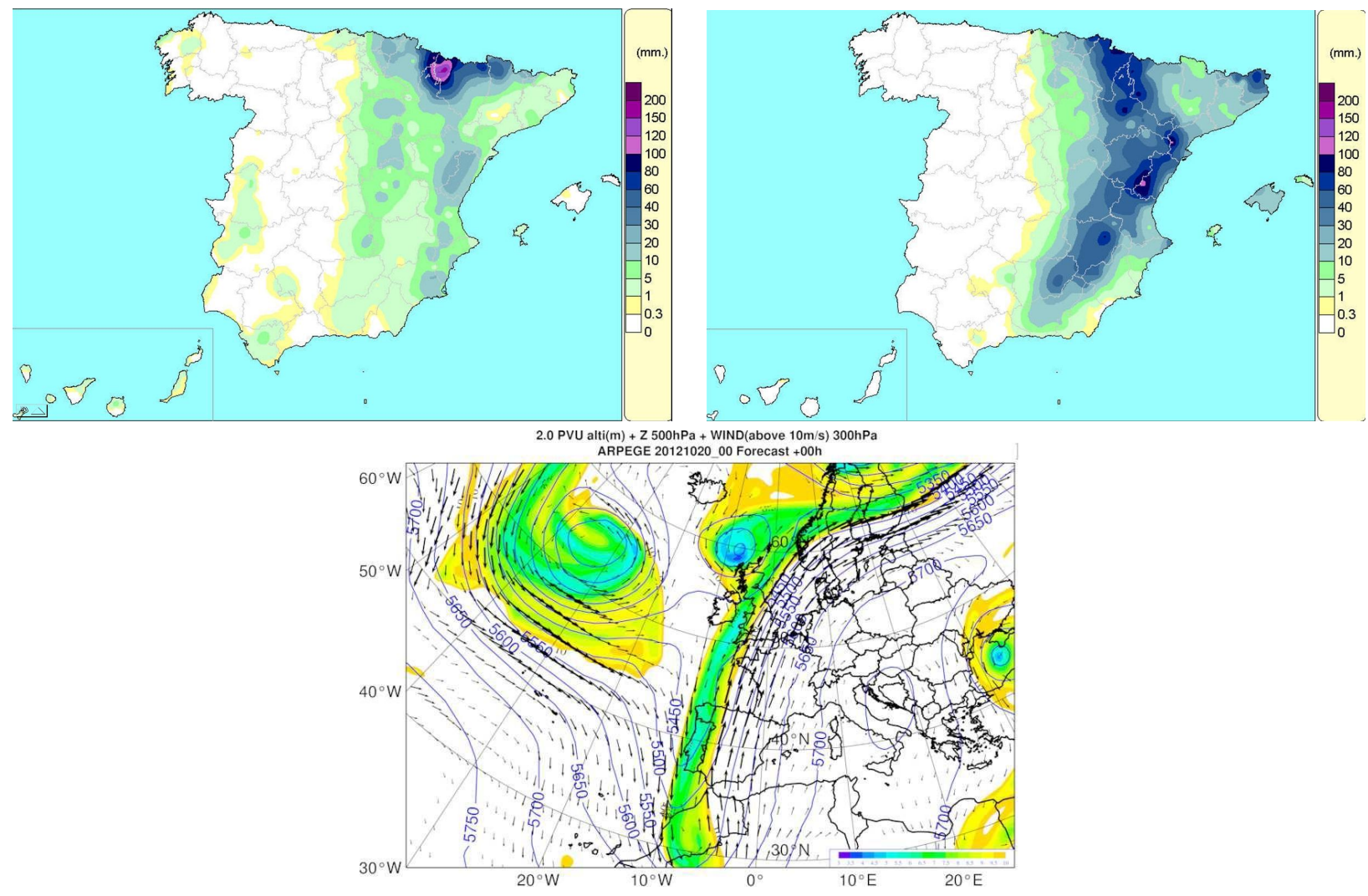

Figure 9. AEMET rainfall analysis (above) for the pluviometric days, the 19th (left) and 20th (right) October 2012 (provisional data from the automatic stations). Situation at high, on the 20th at 00 UTC (below, left), according to ARPEGE analysis, altitude of 2.0 PVU below 10 $\mathrm{km}$ (color), geopotential at $500 \mathrm{hPa}$ and wind at $300 \mathrm{hPa}$ are specifically shown (data provided by Météo-France, from the specific website open for the HyMeX SOP1).

ure 9, with a maximum of $140 \mathrm{~mm}$ at Arauel (Castelló) and $121 \mathrm{~mm}$ at Horta de St. Joan (Tarragona). In the Balearic Islands, rain was not significant.

The ATR42 explored the feeding area of the convection, on the 20th, from 10 UTC until 15:20 UTC, from Montpellier to Montpellier, with a stopover in Menorca, and the Falcon F20 was taking measurements in the convective area of the lower Ebro, on the same day, the 20th, at about 1415:30 UTC (Figure 10). In addition, a constant-level balloon (B23) made a flight from Menorca to near Catalonia, between $06: 30$ and 12 UTC.

There were extraordinary soundings done from Spain on the 18th at 06 UTC (Murcia), the 19th at 18 UTC and the 19th at 06 UTC (Palma and Murcia), the 19th at 18 UTC and the 20th at 06 UTC and 18 UTC (Barcelona, Madrid, Palma and Murcia).

\subsection{Situation on 25th October 2012 (IOP16a)}

This situation, initially defined for Catalonia (on the25th), ended up affecting French (CV) and Italian (LT) regions (on the 26th), with substantial rainfall and very well organized mesoscale convective systems (MCS). The MCS were supported by a southern warm, humid current, as ap- propriate in traditional French cases. The primary cause of perturbed weather was a cold low in height located over the Iberian Peninsula, as usual (Ducrocq et al., 2008; Jansà et al., 2001; Martínez et al., 2008). The IOP16a, probably the most important one in France, is, in any case, one of the three IOPS selected for the SOP1 general compilation article (Ducrocq et al., 2013).

The well-organized MCS began to form later, around midnight between the 25th and 26th, and did not fully affect Catalan lands. In Catalonia, however, there were heavy rains associated to convective structures of a much smaller size than an MCS. Of the AEMET stations, that of Alforja (Tarragona), with $145 \mathrm{~mm}$ (from 07 UTC to 07 UTC) can be highlighted. A nearby MCS station, Riudoms, recorded $148 \mathrm{~mm}$ between 00 UTC and 24 UTC, with maximum intensity, long before the MCS were formed, namely $51 \mathrm{~mm}$ in one hour, between 16 and 17 UTC. This heavy rain, well localized on the radar maps of the Meteorological Service of Catalonia (Figure 11) does not correspond to any large structure on the satellite images that can be qualified as an MCS. Heavy rain in Catalonia provoked some local flooding, which was not too significant.

Extraordinary observations done with aircraft and balloons were very well planned to study the feeding 

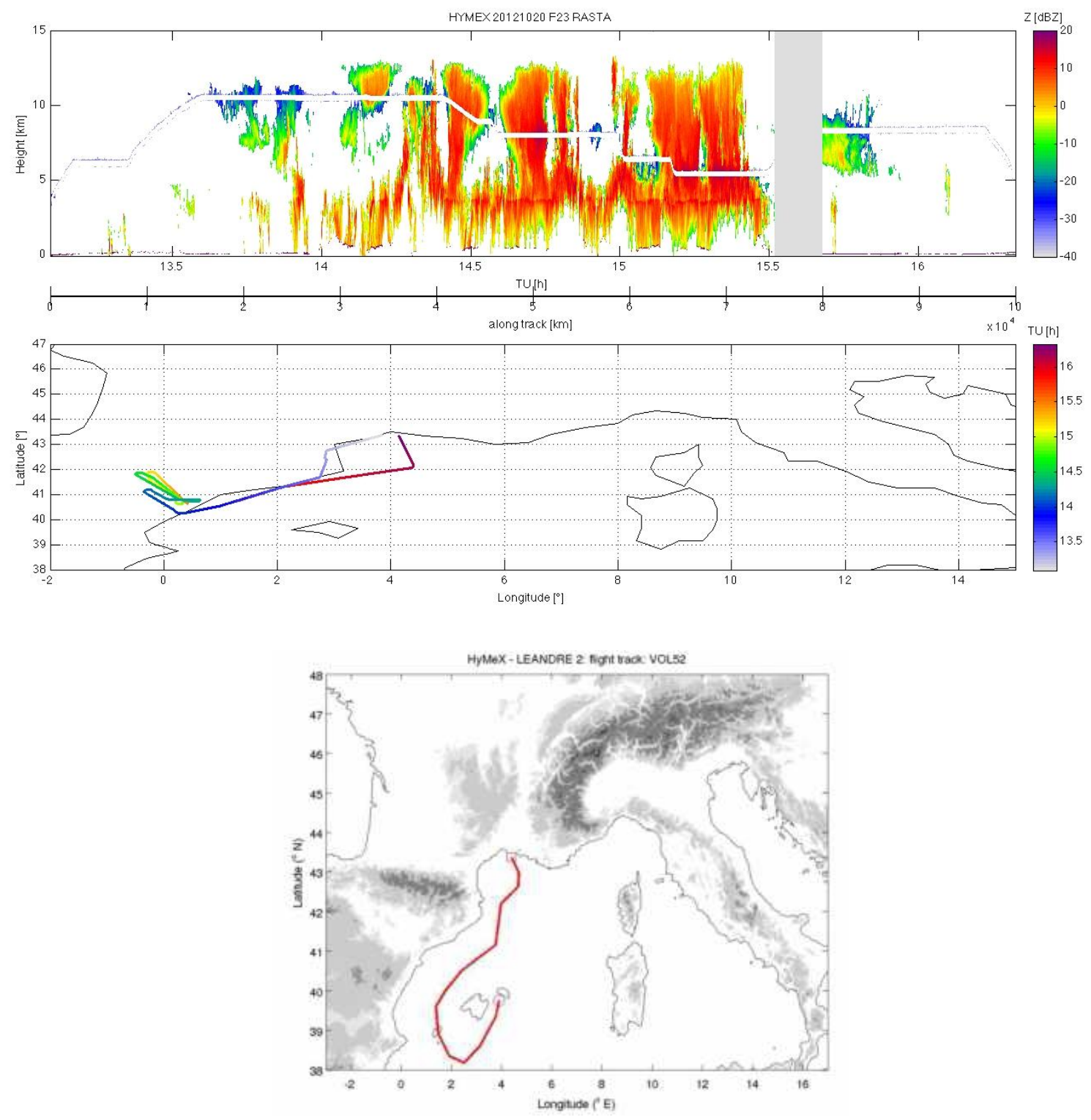

Figure 10. Trajectory Montpellier-Menorca, flight 52 of the ATR42, October 20th, from 10 to 13 UTC (third) and flight of the F20, between 13 and 16:20 UTC, on the same day, the 20th (RASTA, first, and trajectory, second) (data provided by SAFIRE and LATMOS, from the specific website open for the HyMeX SOP1).

area of the MCS, in process of formation and evolution.

A long flight of the ATR42, with a stopover in Ibiza, took place at night, somewhere between the 25th and 26th, and crossed all the marine and coastal area of the Balearic Islands and Catalonia. The flight of the constant-level balloon B26 was also at night, launched from Menorca on the 25th at 21 UTC and finished near Catalonia on the 26th at 03 UTC. Extraordinary DTS soundings were made from all selected stations in Spain on the 24th at 18 UTC and on the 25th at 06 UTC, and at all of them, except Tenerife on the 25 th at $18 \mathrm{UTC}$.

\subsection{Situation of 27 and 28 October 2012}

A strong wind (not heavy rain) IOP was enabled for this situation, specifically IOP16b, but our territories, wrongly, were not included in this statement. In fact, Catalonia and the Balearic Islands were affected by a very active cold front that produced heavy rain on the 27th (the pluviometric day was in fact near the 28th), with a maximum of $89 \mathrm{~mm}$ in Pollença, Mallorca, Balearic Islands. In addition, after the rain strong Tramontana wind blew, as well as strong Mistral and Tramontana winds blew in French land.

There were no operations with constant-level balloons or aircraft in our priority interest areas, but there were 

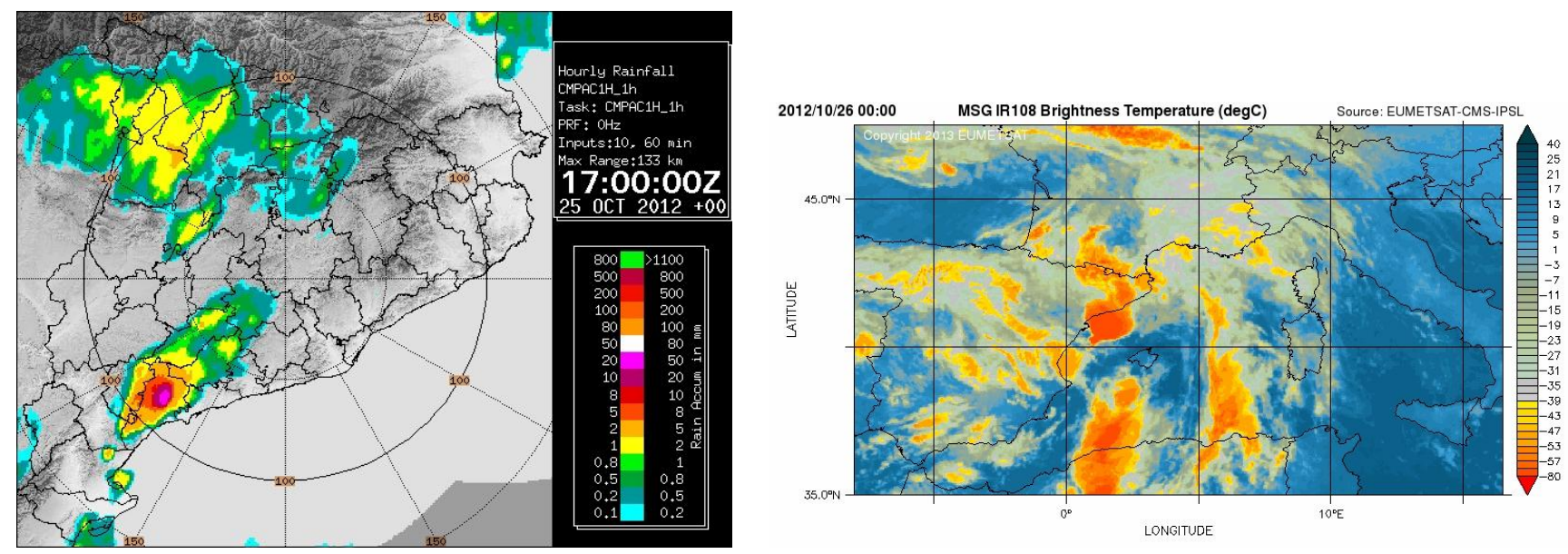

Figure 11. Accumulated rainfall in one hour (until 17 UTC on the 25th), according to the SMC radar (left). The maximum rainfall observed is not related to the formation, much later, of several MCS, with the first of them being quite visible, in front of Catalonia, on the 26th at 00 UTC (right: MSG-IR-10.8, Eumetsat).
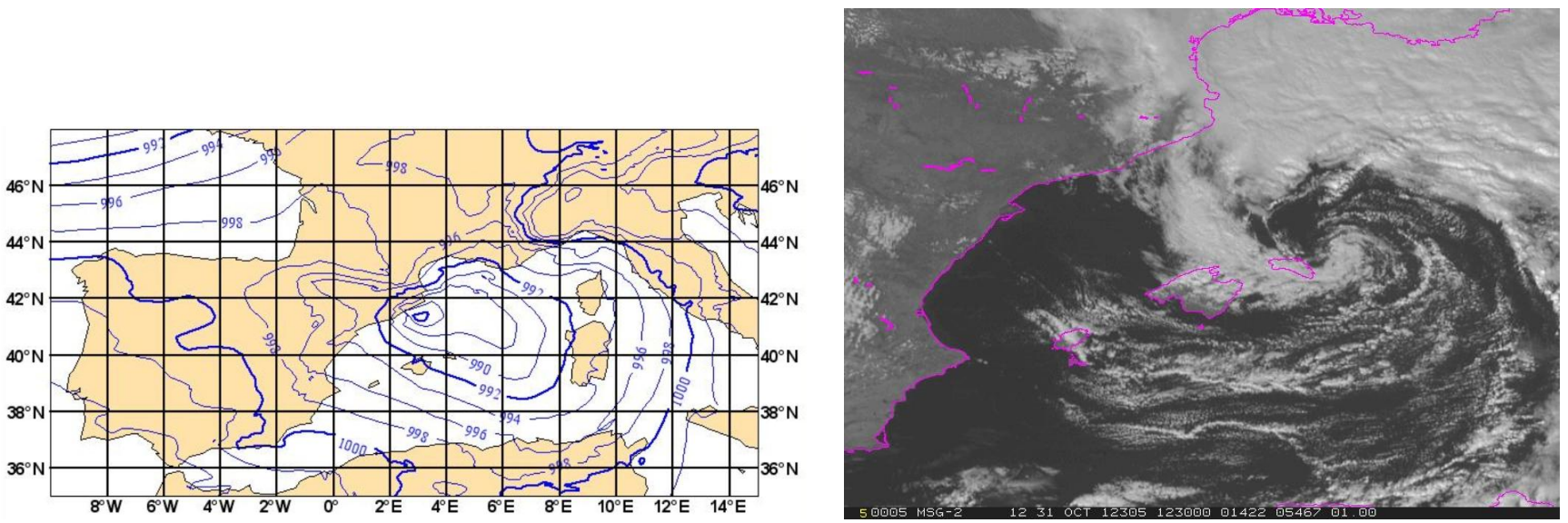

Figure 12. HIRLAM-AEMET prevision $\mathrm{H}+12$ of pressure at sea level for 31 st October at 12 UTC (left) and evidence of the situation of the observed cycle on the 31st at 12:30, MSG-HRVIS (Eutmetsat).

extraordinary DTS soundings. Specifically, ont the 26th at 06 UTC and on the 27th at 06 UTC in all selected stations, except A Coruña and Tenerife, on the 26th at 18 UTC in all selected stations except Tenerife, and on the 27th at 18 UTC only in Palma.

\subsection{Situation on 30th and 31st October 2012}

With a cold low isolated at high levels on the vertical of the Iberian Peninsula, inducing a significant cyclogenesis in the area between Catalonia and the Balearic Islands, the situation suggested heavy rain in Catalonia (according to Jansà et al., 2001; Campins et al., 2007) and strong winds in the Balearic Islands. IOP18 was activated, because of heavy rain at $\mathrm{CA}$ and $\mathrm{BA}$ and because of strong wind at BA.

In some points in the north of Catalonia, $110 \mathrm{~mm}$ were accumulated in 24 hours, not on one pluviometric day, but two, the 30 th and 31 st, from 12 to 12 UTC. In the same period, $60 \mathrm{~mm}$ were accumulated in points of the Balearic Islands. As for the pluviometric day itself (from 07 UTC to 07 UTC), the precipitation maximums were $97 \mathrm{~mm}$, on the 30th, in Blanes, Girona, and $88 \mathrm{~mm}$, on the 31st, in Vilassar de Mar, Barcelona, as recorded in the AEMET weather database.

The cyclone that was formed was small and deep. In fact it had been forecasted, for example, by the HIRLAM0.05-AEMET, as quite intense, but with some differences of location in relation to reality. Figure 12 shows the cyclone forecasted by HIRLAM-AEMET for the 31 st at 12 UTC and the situation, according to the satellite image, on almost the same day at the same time. The cyclone, which was small and very intense, passed right next to Menorca at 12:30 UTC, where the pressure dropped to $986 \mathrm{hPa}$ (one of the lowest pressures recorded at the airport in the forty years of the ob- 

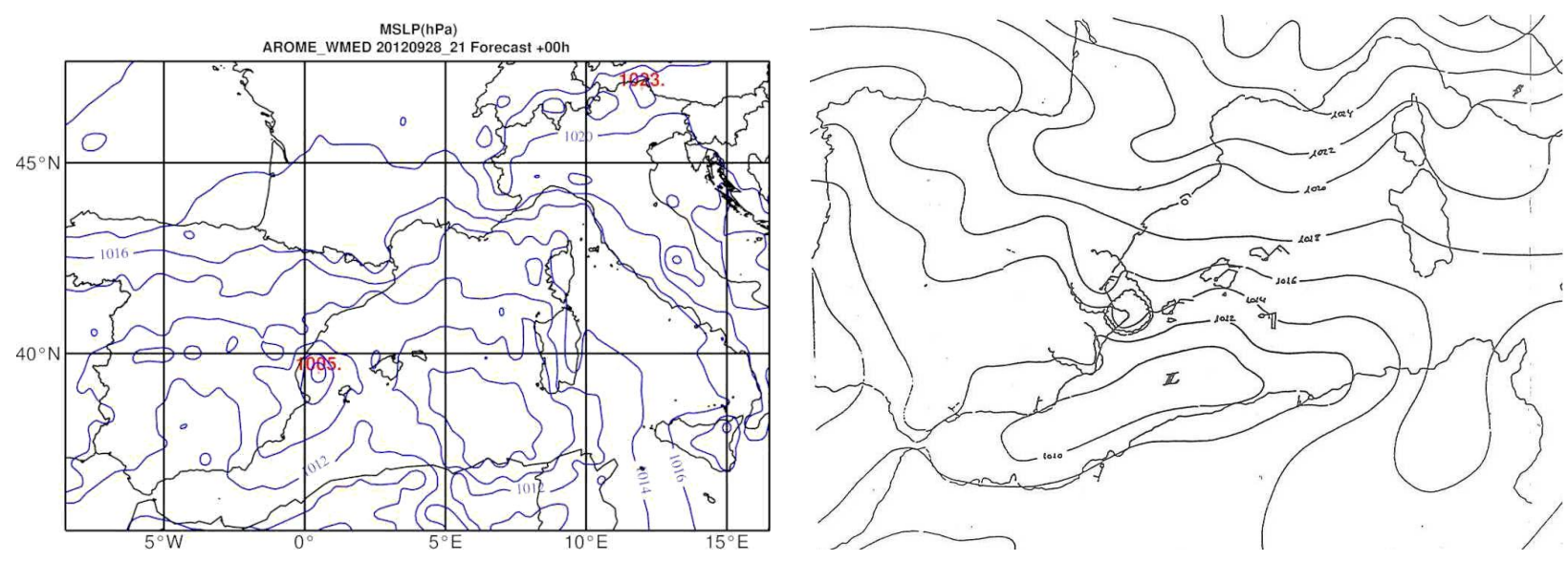

Figure 13. AROME-WMED analysis, 28th September 2012 at 21 UTC (data provided by Météo-France, from the specific website open for the HyMeX SOP1) (left) and manual analysis, 4th November 1987 at 00 UTC, day of record rainfall in the region of Valencia, with indication of the MCS observed (right) (Jansà et al., 1991).

servatory) with a sustained wind of $39 \mathrm{kts}$ with gusts of $63 \mathrm{kts}$ $\left(117 \mathrm{~km} \mathrm{~h}^{-1}\right)$, also some of the strongest ever observed, especially considering that it was a west wind.

No special observations were made in our area, except for extraordinary soundings. On the 30th at 06 UTC, the last observations funded by EUMETNET-EUCOS (from Madrid, Barcelona, Murcia and Palma) were made. Afterwards, the budget available for DTS soundings was over, but three more extraordinary soundings were done, funded by AEMET, in Murcia (the 30th at 18 UTC and the 31st at 06 UTC) and in Palma (the 31st at 06 UTC).

\section{Conclusions}

The first thing that can be said in general is that SOP1, in view of the interest of the situations that occurred and the availability of additional data, is an opportunity to test and tune high resolution numerical models or other prediction methods or systems.

Apart from this, some of the cases were reviewed to highlight some issues that can be considered to be open. The research on these issues (and others that were not raised) can illuminate the processes involved in case of heavy rain or strong wind in the Mediterranean.

As for Spain, the HyMeX SOP1 found and documented a number of significant episodes of extreme weather (heavy rain and strong wind), although some of the more traditional types of situation were not presented. It lacked, for example, a typical MCS episode anchored over the Valencian region of La Safor and/or Marina Alta, fed by an east and northeast maritime long-haul flow, the result of a depression located between the Peninsula, the Balearic Islands and the African coast, and quite stationary (Rivera and Riosalido, 1986; Jansà et al., 1991; Romero et al., 2000; Jansà et al.,
2001). The case of September 28th could have been of this type and what is interesting now is to study why it was not. We believe that we can claim that the reason is that, instead of having a cyclonic centre formed in the optimal place, there were two of them, which also moved relatively quickly. One of the centers was located too close to the region of Valencia, just on the coast, advecting Mediterranean air, but shorthauled, and also on the central coast of the Gulf of Valencia. The other centre, located towards the southeast of the Balearic Islands, could not provide feeding flow to the Valencia area, but to the Balearic Islands. Figure 13 makes a comparison between the situation of 28th September 2012 (AROME analysis) and that of 4th November 1987 (manual analysis), the latter with record rainfall of over $800 \mathrm{~mm}$ in 24 hours (Ramis et al., 2013). The influence of the particular distribution of depression centres on the distribution of rain has to be determined, and this can be done by numerical experimentation. One of the issues that would be implicit would be identification and, in its case, the quantification of the diabatic factor in the genesis of the coastal depression centre. The influence of the position of the disturbance in height in locating the cyclonic centres on surface should also be studied (Romero et al., 2006).

Numerical experiments, in which the factors of localization and characterization of baric centres and their influence on the distribution of rainfall are directly determined, are also interesting for the cases of 12th, 20th and 31st October. On October 12th, in particular, it is interesting to get to understand how a seemingly weak forcing led to a wellorganized MCS with remarkable severity. On the 20th, however, the studied cyclonic centre seemed to be conveniently located, according to the literature, to contribute to heavy rain in southern Catalonia and northern Valencia; sensitivity numerical experiments could confirm this. Incidentally, a forecast for the 21 st of the BOLAM-CNR-ISAC model 
(provided by Silvio Davolio and not shown) that generated a spectacularly small, intense cyclone (a medicane?) on the coast of Valencia was also striking; the medicane (MEDiterranean hurriCANE, Emanuel, 2005) did not occur, but this frustrated forecast highlights the complexity of the interrelations between rain and cyclogenesis. The influence of the diabatic factor, among others, and the relative inaccuracy of the predictions makes the numerical experiment to find out the formation mechanism and the location of intense cyclogenesis of October 31st very interesting.

In all these cases and in those that can be designed to study the cold fronts on 12th September and 27th October, the availability of additional data, either directly or after being incorporated into a refined reanalysis, may better corroborate the results of numerical experiments.

Acknowledgements. This work is a contribution to the HyMeX program and we are indebted to the entire HyMeX organization and the institutions that support it. Much of the information provided comes from AEMET and was made fully available to the authors during HyMeX SOP1 in real and almost real time, although it was later revised. Other data displayed here or just consulted, from various organizations, including French (such as SAFIRE -responsible for aircraft-, LATMOS/IPSL - responsible for the RASTA radar and Météo-France), as well as Italian and Catalan ones, through a site that was established by HyMeX to facilitate the activity related to SOP1. The data and comments regarding the situation of 25 th October were subsequently provided by the Meteorological Service of Catalonia (Montse Aran). AEMET made it possible that during the whole SOP1 there was a fluid relationship through videoconferencing between the Palma Secondary Center and the main Center of Operations of La Grande-Motte. Talks and discussions with the responsible scientists and operations staff at SOP1 (particularly, but not exclusively, Veronique Ducrocq and Evelyne Richard,), and the weather forecasters of Météo-France were very useful for successfully monitoring the campaign. We also thank the two anonymous referees for their contributions, which undoubtedly helped to improve this article.

\section{References}

AEMET, 2012a: Informe Mensual Climatológico - Septiembre 2012, Dpto. Producción, Área de Climatología y Aplicaciones Operativas, http://www.aemet.es/documentos/ es/serviciosclimaticos/vigilancia_clima/resumenes_climat/ mensuales/2012/res_mens_clim_2012_09.pdf.

AEMET, 2012b: Informe Mensual Climatológico - Octubre 2012, Dpto. Producción, Área de Climatología y Aplicaciones Operativas, http://www.aemet.es/documentos/ es/serviciosclimaticos/vigilancia_clima/resumenes_climat/ mensuales/2012/res_mens_clim_2012_10.pdf.

Campins, J., 2013: Radiosoundings (SOP1 and SOP2), HyMeX SOPs' debriefing workshop - 15-17 April 2013, Toulouse, France, www.hymex.org (workshops, SOP_ debriefing, presentations, Monday).

Campins, J., Jansà, A., and Genovés, A., 2006: Heavy rain and strong wind events and cyclones in the Balearics, Advances in Geosciences, 7, 73-77.
Campins, J., Aran, M., Genovés, A., and Jansà, A., 2007: High impact weather and cyclone simultaneity in Catalonia, Advances in Geosciences, 12, 115-120.

Drobinski, P., Ducrocq, V., Alper, P., Anagnostou, E., Béranger, K., Borga, M., Braud, I., Chanzy, A., Davolio, S., Delrieu, G., Estournel, C., Filali Boubrahmi, N., Font, J., Grubisic, V., Gualdi, S., Ivancan-Picek, B., Kottmeier, C., Kotroni, V., Lagouvardos, K., Lionello, P., Llasat, M. C., Ludwig, W., Lutoff, C., Mariotti, A., Richard, E., Romero, R., Rotunno, R., Roussot, O., Ruin, I., Santaner, V., Somot, S., Taupier-Letage, I., Tintore, J., Uijlenhoet, R., and Wernli, H., 2013: HyMeX, a 10-year multidisciplinary program on the Mediterranean water cycle, Bull Amer Meteorol Soc, doi: 10.1175/BAMS-D-12-00242.1.

Ducrocq, V., Nuissier, O., Ricard, D., Lebeaupin, C., and Thouvenin, 2008: A numerical study of three catastrophic precipitating events over Southern France. II: Mesoscale triggering and stationarity factors, Q J R Meteorol Soc, 134, 131-145.

Ducrocq, V., Roussot, O., BŽeranger, K., Braud, I., Chanzy, A., Delrieu, G., Drobinski, P., Estournel, C., Ivancan-Picek, B., Josey, S., Lagouvardos, K., Lionello, P., Llasat, M. C., Ludwig, W., Lutoff, C., Mariotti, A., Montanari, A., Richard, E., Romero, R., Ruin, I., and Somot, S., 2010: HyMeX International Science Plan, http://www.hymex.org/public/documents/ HyMeX_Science_Plan.pdf.

Ducrocq, V., Braud, I., Davolio, S., Ferretti, R., Flamant, C., Jansà, A., Kalthoff, N., Richard, E., Taupier-Letage, I., Ayral, P., Belamari, S., Berne, A., Borga, M., Boudevillain, B., Bock, O., Boichard, J. L., Bouin, M. N., Bousquet, O., Bouvier, C., Chiggiato, J., Cimini, D., Corsmeier, U., Coppola, L., Cocquerez, P., Defer, E., Delanoë, J., Di Girolamo, P., Doerenbecher, A., Drobinski, P., Dufournet, Y., Fourrié, N., Gourley, J. J., Labatut, L., Lambert, D., Le Coz, J., Marzano, F. S., Molinié, G., Montani, A., Nord, G., Nuret, M., Ramage, K., Rison, B., Roussot, O., Said, F., Schwarzenboeck, A., Testor, P., Baelen, J. V., Vincendon, B., Aran, M., and Tamayo, J., 2013: HyMeX-SOP1, the field campaign dedicated to heavy precipitation and flash flooding in the northwestern Mediterranean, Bull Amer Meteorol Soc, doi: 10.1175/BAMS-D-12-00244.1.

Emanuel, K., 2005: Genesis and maintenance of "Mediterranean hurricanes", Advances in Geosciences, 2, 217-220.

Font, I., 1983: Climatología de España y Portugal, Instituto Nacional de Meteorología, Madrid, 296 pgs.

Jansà, A., 2013: Heavy precipitation and flash flood events in Spain, HyMeX SOPs' debriefing workshop - 15-17 April 2013, Toulouse, France, www.hymex.org (workshops, SOP_ debriefing, presentations, Tuesday).

Jansà, A., García-Moya, J. A., and Rodríguez, E., 1991: Numerical experiments on heavy rain and Mediterranean cyclones, WMO/TD No. 420, pp. 37-47.

Jansà, A., Genovés, A., Picornell, M. A., Campins, J., Riosalido, R., and Carretero, O., 2001: Western Mediterranean cyclones and heavy rain. Part 2: Statistical approach, Meteorol Appl, 8, 43-56.

Jansà, A., Arbogast, P., Doerenbecher, A., Garcies, L., Genovés, A., Homar, V., Klink, S., Richardson, D., and Sahin, C., 2011: A new approach to sensitivity climatologies: the DTS-MEDEX2009 campaign, Nat Hazards Earth Syst Sci, 11, 2381-2390.

Llasat, M. C., Llasat-Botija, M., Prat, M. A., Porcu, F., Price, C., Mugnai, A., Lagouvardos, K., Kotroni, V., Katsanos, D., Michaelides, S., Yair, Y., Savvidou, K., and Nicolaides, K., 2010: High-impact floods and flash floods in Mediterranean countries: 
the FLASH preliminary database, Advances in Geosciences, 23, 47-55.

Llasat, M. C., Llasat-Botija, M., Petrucci, O., Pasqua, A. A., Rosselo, J., Vinet, F., and Boissier, L., 2013: Towards a database on societal impact of Mediterranean floods within the framework of the HYMEX project, Nat Hazards Earth Syst Sci, 13, 13371350.

Martínez, C., Campins, J., Jansà, A., and Genovés, A., 2008: Heavy rain events in the Western Mediterranean: an atmospheric pattern classification, Advances in Science and Research, 2, 61-64.

Quintana, P., Homar, V., Llasat, M. C., Jansà, A., Font, J., and Aran, M., 2012: A look to the HyMeX program, Tethys, 9, 63-74, doi: 10.3369/tethys.2012.9.06.

Ramis, C., Homar, V., Amengual, A., Romero, R., and Alonso, S., 2013: Daily precipitation records over mainland Spain and the Balearic Islands, Nat Hazards Earth Syst Sci, 13, 2483-2491, doi: 10.5194/nhess-13-2483-2013.

Rivera, A. and Riosalido, R., 1986: Mediterranean convective systems as viewed by Meteosat: A case study, 6th Meteosat Scientific Users Meeting, 25-27 November 1986, EUMETSAT, Amsterdam, pp. 101-104

Romero, R., Doswell, C. A., and Ramis, C., 2000: Mesoscale numerical study of two cases of long-lived quasi-stationary convective system over eastern Spain, Mon Weather Rev, 128, 37313751.

Romero, R., Martín, A., Homar, V., Alonso, S., and Ramis, C., 2006: Predictability of prototype flash flood events in the western Mediterranean under uncertainties of the precursor upper-level disturbance, Advances in Geosciences, 7, 55-63. 